\title{
A Case of Organizing Hematoma of the Nasal Septum
}

\author{
Min Su Ha, Yong Jin Song, Kyung Yuhl Han and Nam-Kyung Yeo \\ Department of Otolaryngology, Gangneung Asan Hospital, College of Medicine, University of Ulsan, Gangneung, Korea
}

\section{비중격에서 기원한 기질화 혈종 1 예}

하민수 · 송용진 · 한경열 · 여남경

울산대학교 의과대학 강릉아산병원 이비인후과학교실

\author{
Received December 7, 2009 \\ Revised April 6, 2010 \\ Accepted April 15, 2010 \\ Address for correspondence \\ Nam-Kyung Yeo, MD, PhD \\ Department of Otolaryngology, \\ Gangneung Asan Hospital, College \\ of Medicine, University of Ulsan, \\ 415 Sacheon-myeon, Bangdong-ri, \\ Gangneung 210-711, Korea \\ Tel $+82-33-610-3308$ \\ Fax $+82-33-641-8148$ \\ E-mail nkyeo@gnah.co.kr
}

Organizing hematomas are rare benign tumors and appear as forms of mass which is composed of neovascularization with organizing fibrous tissue in hematoma. There have been sporadic reports of the organizing hematoma not only in soft tissue but also in brain, spinal cord, lung, and maxillary sinus. We report a case of organizing hematoma that was restricted in the nasal cavity without inclusion of the paranasal sinus. This is the first article describing the organizing hematoma of the nasal septum. We present this case with a review of literature.

Korean J Otorhinolaryngol-Head Neck Surg 2010;53:324-6

Key Words Organizing hematoma $\cdot$ Nasal cavity $\cdot$ Maxillary sinus $\cdot$ Tumor.

\section{서 론}

기질화 혈종은 여러 가지 원인으로 인해 혈종이 형성된 후 그 안에 혈관이 신생되고 섬유화가 진행되는 기질화 과정을 거치면서 종괴의 형태로 나타나는 드문 양성 질환이다. ${ }^{1,2)}$ 혈종의 원인은 안면부의 외상으로 인한 출혈이나 비강 내의 혈관 분지 파열에 의한 출혈 혹은 점막하 출혈, 부비동 수술 후의 출혈, 혈관종 및 동맥류를 포함한 다양한 혈관 질환으 로 인한 출혈 등이 있으며 그 외 특별한 원인 없이 생기기도 한다. 두개내, 척수내, 근골격계 및 연부조직에서 발생한 것 이 주로 보고되어 있고, ${ }^{1,2)}$ 비부비동 내에서 발생한 경우는 상악동 내에서 발생한 증례들 밖에 없다. ${ }^{3,4)}$ 저자들은 부비동, 특히 상악동과 관련 없이 비중격에서 발생하여 비강 내에만 국한된 기질화 혈종을 경험하였고 이러한 경우는 현재까지 보고된 바 없어 문헌 고찰과 함께 보고하는 바이다.

\section{증레}

35 세 여자 환자가 1 개월 전부터 발생한 우측의 간헐적
비출혈을 주소로 내원하였다. 문진상 우측의 암적색 비루 및 비폐색증상을 호소하였고 그 외 비증상은 호소하고 있지 않 았다. 환자는 외상이나 수술 등의 과거력은 없었으며, 가족력 상에서도 특이사항은 없었다. 일반 혈액검사 및 일반 화학 검사, 혈액응고검사는 모두 정상이었다. 코 내시경 소견상 우측 중비갑개 앞쪽 비판부위에 출혈성향이 강한 암적색의 종물이 관찰되었고 기시부 외에 하비갑개나 비강저, 비인두 와의 연관성은 관찰되지 않았으며 비용, 분비물, 점막 이상 등은 보이지 않았다(Fig. 1). 부비동 전산화단층촬영 소견상 우측 비중격에서 기원된 이질적인 조영증강을 보이는 종괴 가 관찰되었으며 그 외 다른 부비동의 병변 및 골벽의 침윤 소견은 보이지 않았다(Fig. 2). 화농성 육아종이나, 혈관종 또는 기질화 혈종 의심하에 전신마취하 비내내시경 접근으 로 종괴의 전절제술을 계획하였다. 종괴의 기시부인 우측 비 중격의 점막을 포함하여 종괴를 일괴로(en bloc) 완전히 제 거하였다. 적출된 종괴는 약 $1 \times 1.5 \mathrm{~cm}$ 크기의 경계가 잘 형성된 암적색의 불규칙한 표면을 가졌다. 병리조직학적 소 견은 혈종 주위 섬유막이 잘 형성되어있고 종괴 내부에는 혈관에서 누출된 많은 적혈구를 동반한 풍부한 신생혈관들 
과 섬유세포들 및 섬유화 과정이 관찰되어 기질화 혈종으로 진단되었다(Fig. 3). 환자는 수술 4 일째에 퇴원하였고 술 후 8 개월까지 재발 및 특이 증상 없이 관찰 중이다(Fig. 4).

\section{고 찰}

기질화 혈종은 드물게 발생하는 양성 종양으로 어느 부위 에나 생길 수 있지만 대부분 연부조직, 두개내, 척수내, 근골 격계, 부신, 폐, 인두주위 공간 및 비부비동 내에서의 발생이 보고되고 있다. ${ }^{3-5)}$ 특히 비부비동 내에서 발생한 것은 1917 년 일본에서 처음으로 보고된 이래 상악동 내에서의 발생

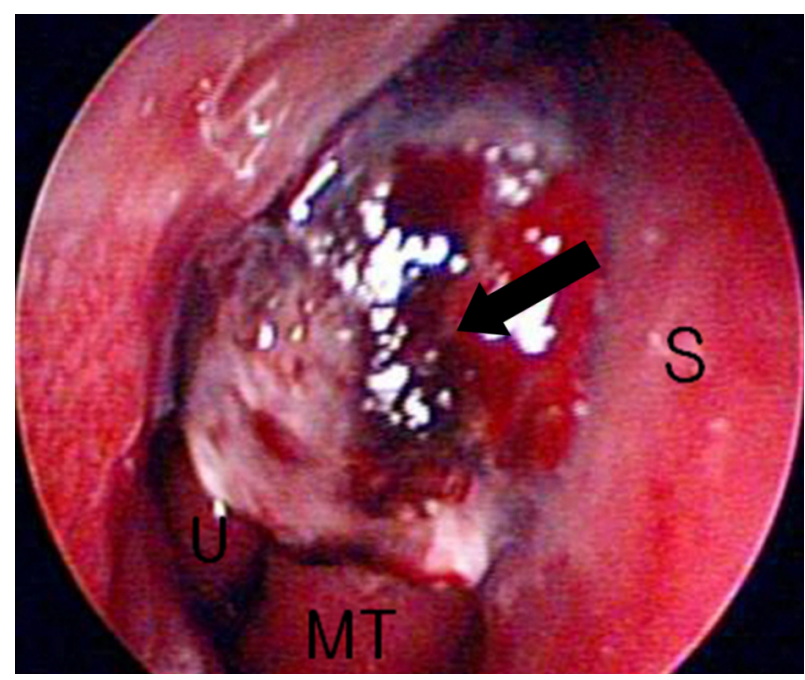

Fig. 1. Preoperative nasal endoscopic findings. The arrow indicates the reddish mass in the right internal nasal valve area. The mass showed easily bleeding tendency. MT: middle turbinate, S: nasal septum, U: uncinate process.
만 드물게 보고되고 있다. ${ }^{6)}$

기질화 혈종의 원인이 되는 혈종의 기원에 대한 기전은 비 강 내 출혈이 상악동 내로 유입되었거나 상악동 내 점막하 출혈로 발생된 혈종이 불완전한 환기 및 배액으로 인해 혈 관이 신생되고 섬유화가 진행되는 기질화 과정을 거쳐서 종 괴의 형태로 나타나는 것으로 생각되고 있다. ${ }^{7)}$ 본 증례에 서는 비강 내에만 국한된 기질화 혈종을 보였는데, 이는 혈 종이 상악동처럼 많은 양의 혈액이 안정적으로 고일 수 있 는 부위에서만 생기는 것이 아니라 비강 내에서 적은 양의 혈액이라도 오랜 시간의 환기나 배액 장애 없이도 혈종 안 에서 섬유화나 혈관생성 등의 과정이 쉽게 발생할 수 있음 을 시사하고 있다. 다른 이유로는 상악동에 비해 비중격 전 방 등의 비강 앞쪽의 공간은 미세 자극이 더 많은 부위이다.
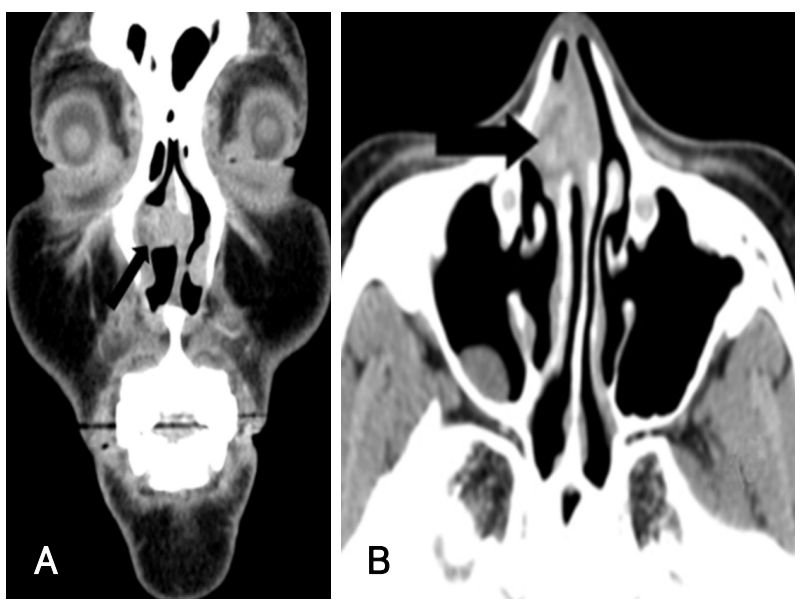

Fig. 2. Preoperative CT scans of organizing hematoma in the right nasal cavity. Heterogenous enhancement of the mass (arrow) is noted in coronal $(A)$ and axial $(B)$ view.
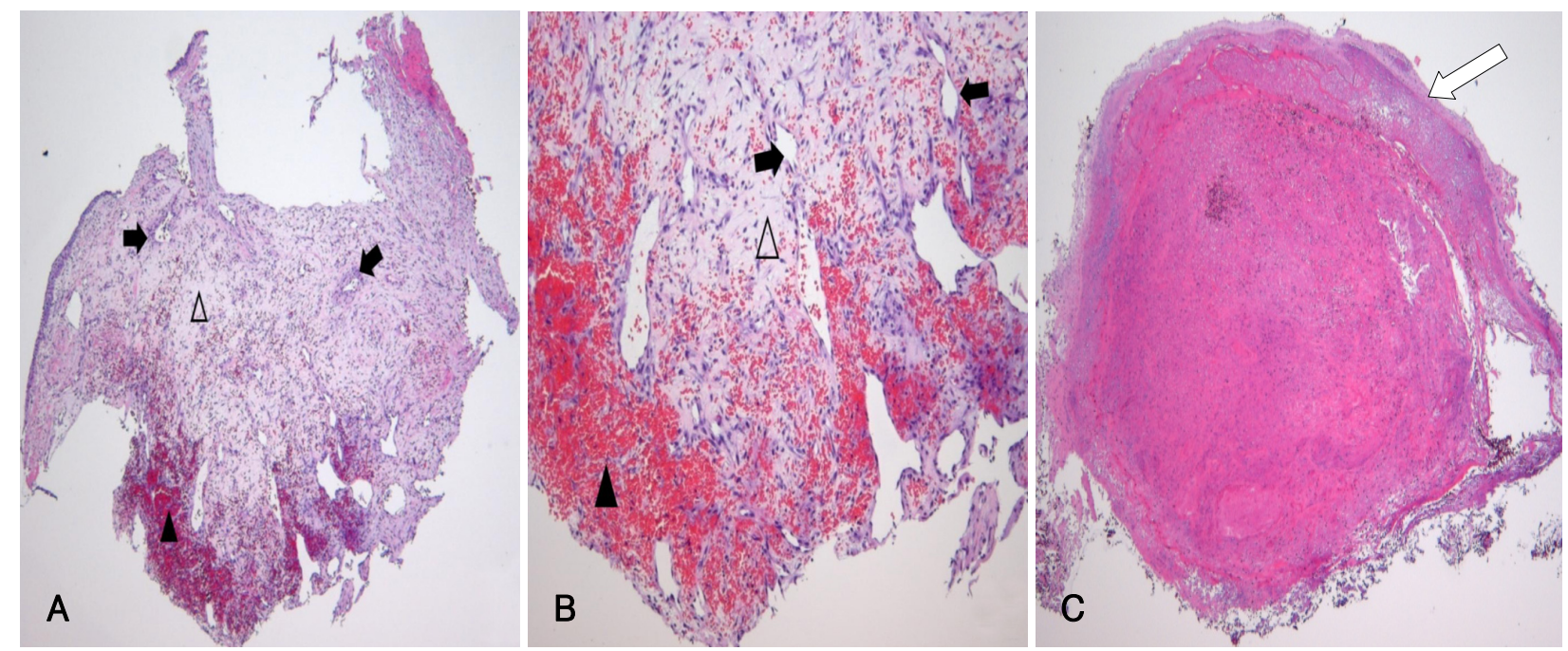

Fig. 3. Histopathologic finding of organizing hematoma. Organizing hematoma is composed of angiogenesis (black arrow), fibrosis (open arrowhead), extravasated red blood cells (black arrowhead) and fibrous capsule (white arrow). H\&E, $\times 40$ (A), $\times 200$ (B), $\times 20$ (C). 


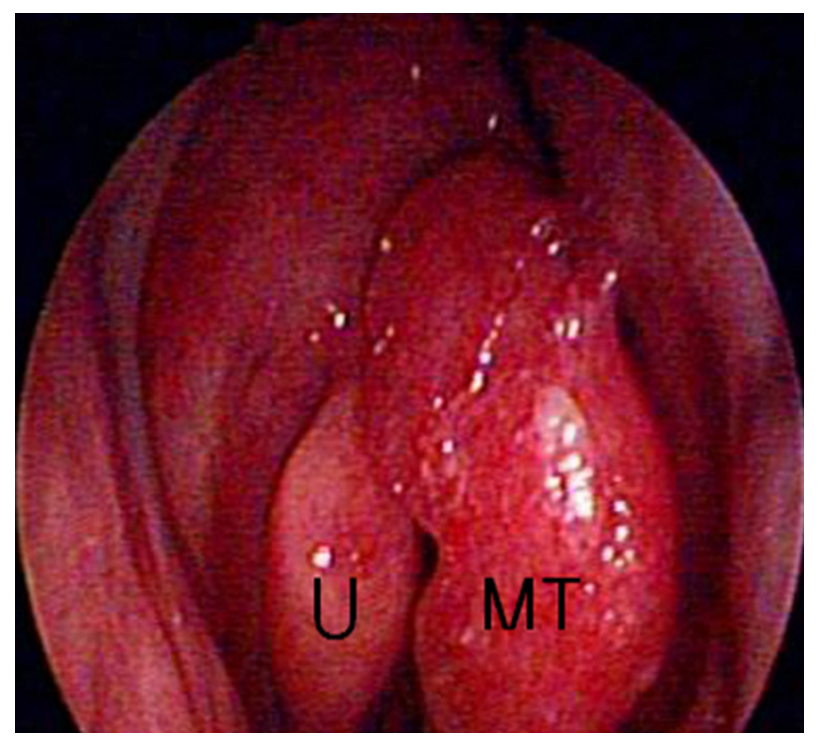

Fig. 4. Postoperative nasal endoscopic findings. After 3 months, septal mucosa which the mass originated in, was completely healed in the right nasal cavity. MT: middle turbinate, U: uncinate process.

실제로 비중격 전방부위에 많이 발생하는 소엽성 모세혈관 종은 미세 외상이 주 원인으로 보고되고 있다.,9) 이와 같이 적은 양의 혈종이 생겨도 미세 자극을 많이 받게 되면 섬유 화 등의 기질화 과정이 빨리 진행되어 비강 내에만 국한된 기질화 혈종이 발생할 수 있을 것으로 짐작된다.

기질화 혈종의 임상 증상으로는 본 증례처럼 비폐색이나 반복적인 비출혈 그 외에 후각저하, 두통, 협부 종창 등이 있을 수 있고 상악동 내 또는 점막하 출혈에 국한된 경우에 는 비출혈이 없을 수도 있다. 진단은 병력 청취와 비내시경 등을 이용한 진찰 소견 및 전산화단층촬영 등의 영상검사 를 이용하지만 대부분 환자의 병력이 반복적 비출혈 및 비 폐색증 등으로 비특이적이며 비내시경 소견 역시 출혈성향 이 강한 종괴로 보여 육안적으로는 화농성 육아종, 혈관종, 악성 흑색종 및 악성 종양과 감별하기 어렵다. 부비동 전산 화 촬영상 이질적인 조영 증강을 보여 역시 악성종양과 정 확한 감별진단이 어렵고 특히 본 증례처럼 30대 여자에서 편측 비강 내 비중격 앞 쪽에 발생한 출혈성 종괴가 있을 경 우 화농성 육아종, 즉 소엽상 모세관혈관종(lobular capillary hemangioma) 과의 임상적인 감별이 어렵기 때문에 결 국 확진은 술 후 생검으로 가능하게 된다.

기질화 혈종은 조직학적으로 섬유화막(fibrous capsule) 으로 잘 둘러싸인 혈종 내에 섬유화에 의한 무정형성 섬유질 (amorphous fibrin mass) 과 적혈구, 신생혈관 등이 혈종과 혼재되어 나타나는 소견을 보인다. 반면에 소엽성 모세관 혈
관종의 경우 혈종의 형성이 분명하지 않고 대신 점액 섬유 종의 기질(fibromyxoid stroma)에 소엽성 모세혈관종이 흩어져 있는 특징을 나타낸다. ${ }^{8)}$ 이러한 차이는 기질화 혈종 의 발생기전에 있어 일차적으로 혈종이 먼저 형성되어야 하 는데 기인한다고 볼 수 있다.

치료는 본 증례처럼 단순히 비강 내에 국한된 경우에는 비내 내시경 접근으로 충분하다. 하지만 상악동에 같이 병발 한 경우 정상 점막과 기질화 혈종의 구분이 불명확하고 박 리가 쉽게 되지 않으면 비내 수술과 함께 Caldwell-Luc operation및 Denker operation 등을 같이 시행할 수 있다. 대부분 상악동 내의 기질화 혈종이 발생 초기에는 증상이 없다가 종괴 크기가 증가하면서 비출혈, 비폐색 등의 증상이 보이는 반면, 비강 내 발생한 기질화 혈종은 상악동 기질화 혈종에 비해 상대적으로 빠른 비출혈 및 비폐색 증세로 임 상적으로 조기 진단이 가능하다. 또한 상악동 내의 기질화 혈종은 진단이 늦어지는 경우가 많아 진단 당시 상악동 골벽 의 파괴를 보여 악성종양으로 의심될 수 있으나, ${ }^{4)}$ 비강 내 에 국한된 경우 혈종의 크기가 상대적으로 더 작아 방사선 학적으로는 골파괴 현상 역시 심하지 않고, 치료로도 간단한 내시경 수술만으로 완전 절제가 가능하다는 특징을 가진다. 이번 증례와 같이 잦은 비출혈이 있는 환자가 비강 내에 서만 국한된 암적색의 종괴를 보일 때에 단순 육아조직, 소 엽성 모세관 혈관종, 비용종 등과 함께 기질화 혈종을 감별 진단에 반드시 포함시켜야 한다고 사료된다.

\section{REFERENCES}

1) Ito $\mathrm{M}$, Tajima $\mathrm{A}$, Sato $\mathrm{K}$, Ishii S. Calcified cerebellopontine angle hematoma mimicking recurrent acoustic neuroma. Clin Neurol Neurosurg 1988;90 (1):65-70.

2) Lee YY, Moser R, Bruner JM, Tassel P. Organized intracerebral hematoma with acute hemorrhage: $\mathrm{CT}$ patterns and pathologic correlations. AJR Am J Roentgenol 1986;147 (1):111-8.

3) Lee BJ, Park HJ, Heo SC. Organized hematoma of the maxillary sinus. Acta Otolaryngol 2003;123 (7):869-72.

4) Song HM, Jang YJ, Chung YS, Lee BJ. Organizing hematoma of the maxillary sinus. Otolaryngol Head Neck Surg 2007;136 (4) :616-20.

5) Wen-Shou Hsu, Shiu-Fen Liu, Sau-Tung Chu,Hui-Hwa Tseng. An Organizing Hematoma in the Parapharyngeal space. J Chin Med Assoc 2009;72(2):94-7.

6) Yagisawa M, Ishitiya J, Tsukuda M. Hematoma-like mass of the maxillary sinus. Acta Otolaryngol 2006;126(3):277-81.

7) Park EH, Lee SS, Sung SH. Maxillary sinus mucocele secondary to organized Hematoma. Korean J Otolaryngol-Head Neck Surg 2007; 50 (11):1073-6.

8) Park SK, Cho HW, Jang SH, Park CK. Clinical study of lobular capillary hemangioma in nasal cavity. Korean J Otolaryngol-Head Neck Surg 2000;43 (4):402-5.

9) Vilmann A, Vilmann P, Vilmann H. Pyogenic granuloma: evaluation of oral conditions. Br J Oral Maxillofac Surg 1986;24 (5):376-82. 